\title{
The Gendered Experiences of Male Students in a Speech- Language Pathology Graduate Program: A Multi-Case Study
}

Jairus-Joaquin R. Matthews

University of West Georgia, jmatthew@westga.edu

Derek E. Daniels

Wayne State University, dedaniels@wayne.edu

DOI: https://doi.org/10.30707/TLCSD3.2Matthews

Follow this and additional works at: https://ir.library.illinoisstate.edu/tlcsd

Part of the Gender and Sexuality Commons, Higher Education and Teaching Commons, and the Speech Pathology and Audiology Commons

\section{Recommended Citation}

Matthews, Jairus-Joaquin R. and Daniels, Derek E. (2019) "The Gendered Experiences of Male Students in a Speech-Language Pathology Graduate Program: A Multi-Case Study," Teaching and Learning in Communication Sciences \& Disorders: Vol. 3: Iss. 2, Article 2.

DOI: https://doi.org/10.30707/TLCSD3.2Matthews

Available at: https://ir.library.illinoisstate.edu/tlcsd/vol3/iss2/2

This Scholarship of Teaching and Learning Research is brought to you for free and open access by ISU ReD: Research and eData. It has been accepted for inclusion in Teaching and Learning in Communication Sciences \& Disorders by an authorized editor of ISU ReD: Research and eData. For more information, please contact ISUReD@ilstu.edu. 


\title{
The Gendered Experiences of Male Students in a Speech-Language Pathology Graduate Program: A Multi-Case Study
}

\author{
Abstract \\ Speech-language pathology is a profession with a gender disparity wherein the majority of speech- \\ language pathologists are female. This disparity is also reflected in speech-language pathology graduate \\ programs. The American Speech, Language, and Hearing Association has developed many initiatives over \\ the years to address this issue, yet the gender disparity still remains. The purpose of this study was to \\ develop some initial insights into reasons that men enter into the profession of speech-language \\ pathology, and their experiences in graduate programs. In this qualitative case-study approach, interviews \\ were conducted with four male graduate students. The interviews were transcribed and analyzed for \\ major themes. Results suggest that though gender did not directly influence the participants' reasons for \\ pursuing speech-language pathology as a profession, it did influence, to various degrees, their \\ experiences in graduate programs. This study documented how some male students students in speech- \\ language pathology developed critical strategies, intentional ways of adjusting to, and succeeding in their \\ female-majority educational and social environment. Participants discussed the ways in which gender \\ influenced their social group dynamics, study group dynamics, and clinical interactions with clients. This \\ study bears implications for the ways that we might recruit male students into speech-language \\ pathology, and help them have success in graduate school.
}

\section{Keywords}

speech-language pathology, gendered discourses, case study, career choice

\section{Cover Page Footnote}

In this article, the terms men and women are used to define sexed gender identities. The authors acknowledge that gender is non-binary, undefined, and socially constructed- and that many people, including persons in reviewed studies and the present study may not subscribe to these labels 


\section{Introduction}

The lack of male speech-language pathologists has long been a concern of practitioners, clinical educators, and the American Speech, Language, and Hearing Association (ASHA) (RowdenRacette, 2013). In a November 1994 special-themed issue of The ASHA Journal, there was a focus on gender in the professions of speech-language pathology and audiology. In the issue, it was announced that ASHA would be beginning a pilot recruitment project in collaboration with the Council of Graduate Programs in Communication Sciences and Disorders (CGPCSD). Since that time, the association has commissioned studies, developed marketing campaigns, and worked with a number of organizations to recruit men into the profession (Rowden-Racette, 2013). However, these efforts have yielded few positive results as the number of men in speechlanguage pathology has steadily declined. For example, $3.7 \%$ of certified speech-language pathologists were males in 2016, whereas $4.4 \%$ and $6 \%$ of certified speech-language pathologists were males in 2005 and 1993, respectively (ASHA, 2007, 2016a; Werven, 1994). This represents a $16 \%$ decrease in the past decade and a $38 \%$ decrease over the last two decades.

The push for more male SLPs is based on the belief that an overwhelming female workforce in the profession does not reflect the client population that it serves, especially in professions like speech-language pathology where the majority of clients tend to be male (Litosseliti \& Leadbeater, 2013). For example, boys are more at risk for articulation disorders, fluency disorders, and childhood voice disorders (Carding, Roulstone, \& Northstone, 2006; Hegde, 2010; Pena-Brooks \& Hegde, 2007). Autism spectrum disorder and traumatic brain injury, two high yielding causes of communication disorders, are also significantly more prevalent in males (CDC, 2016; Christensen, et al., 2016). Male recruitment was a strategic goal for ASHA in the 1990s because it was deemed critical for the ASHA membership to "reflect the broadest social and multicultural diversity of society" (Goldberg, 1994, p. 39). Further, research has suggested that in professions such as teaching, students may trust and respect someone with whom they share a salient physical characteristic, and that this connection lends itself to better learning outcomes for the student (Dee, 2004; Egalite, Kisida, \& Winters, 2015). However, most of the research related to the importance of shared physical characteristics between teachers and students is based on race and not gender. Research linking men teachers or professionals to improved academic or health outcomes for clients has been described as tenuous at best in education (Cushman, 2008), and essentially non-existent in other fields like speech-language pathology and nursing.

Researchers have contended that the intentional recruitment of men into education is a response to the perceived feminization of teaching (Griffith, 2006; Martino, 2008). They have argued that this educational reform is anchored within a hegemonic masculinity that emphasizes individualism, compulsory heterosexuality, toughness, competition, and aggressiveness (Connell \& Messersschmidt, 2005). For example, Mallozzi and Galman (2015) critiqued the "add men and stir" approach to early childhood education by illustrating how both men and women positioned male early childhood educators as militaristic disciplinarians in opposition to the feminized caring and nurturing roles of women in the same workplace. Men were considered to be incompetent nurturers, but yet more capable of "masculine" aspects of their careers that were highly differentiated along gender lines. Another frequently cited reason for the recruitment of men into education is for them to serve as "role models" for boys who are often marginalized within the educational system (Dermott, 2012).Yet, the responsibilities of being a male role model are somewhat convoluted and undefined. Cushman (2008) investigated the beliefs of 
primary school principals in New Zealand and found that over $90 \%$ of administrators wanted more male teachers in elementary schools to compensate for the lack of adult male role models in single-parent homes (particularly for boys). The authors concluded that the underlying rationale for this was to reinforce dominant masculinities. These included qualities that were perceived to be in opposition to femininity or homosexuality such as toughness, aggressiveness, strictness, protectiveness, and being less emotional and complicated. Less than $7 \%$ of the principals implicated the need for male teachers to deconstruct stereotypes by demonstrating perceived feminine qualities such as being gentle, caring, and compassionate, and communicative of feelings and emotions.

Despite some reservations about the patriarchal impetus for male recruitment, there are multiple reasons that stakeholders such as ASHA, hiring managers, administrators, and speech-language pathologists want to address the lack of male SLPs. There is a very stark contrast in gender between the majority of clients in both pediatric and adult settings, and the clinicians in the field (Litosseliti \& Leadbeater, 2013). Therein lies the question of how an overwhelmingly White, female, middle-class workforce can relate to and motivate a very diverse population of clients. A greater gender balance (as well as racial, ethnic, and cultural) could also contribute to greater diversity in professional practices, services, and perspectives while also inadvertently creating more awareness of the profession (Litosseleti \& Leadbeater, 2013).

Despite the lack of success in recruitment, increasing the number of males in the profession remains a cornerstone goal for ASHA. For example, "Objective 6" of ASHA's Strategic Pathway (ASHA, 2015) focuses on increasing the diversity of the membership, including bilingual service providers, underrepresented racial and ethnic backgrounds, and men. Rowden-Racette (2013) reported that ASHA-commissioned studies by consulting firms in 2004 and 2009 (not publicly available) revealed that men are not choosing speech-language pathology as a career due to salary concerns, gender stereotypes, an inequitable gender dynamic in the field, and lack of awareness of the field. ASHA has recently initiated a male recruitment campaign by developing a male recruitment microsite and a male recruitment center at the national convention, launching a project for a mentor/mentee matching tool, and consulting with guidance counselors at highly diverse STEM based high schools (ASHA, 2018). ASHA has made it clear that these efforts toward greater diversity in speech-language pathology are critical to continuing to serve our clients. The contention in this article is that we must study not only the reasons men enter speech-language pathology but also their experiences and challenges within their training programs. In order to continue to advance these efforts, it is necessary to review what is known about the choices of men who enter female-majority professions, as well as the experiences that they encounter in their training. It should be noted that the vast majority of the research on male speech-language pathologists has been conducted in the United Kingdom and Australia with little research being conducted on male students and SLPs in the United States. Because few studies have focused on speech-language pathology and gender, research on gender disparities in other professions is discussed as well.

\section{Gender Differences in Career Choices and Experiences}

Gender refers to the process of dividing people and behaviors based on sexual identities (Beasley, 2005). It is the naming, inscribing, and categorizing of humans as boys or girls and men and women. Gender is a social construction that describes the ideas and practices that establish what is considered to be feminine or masculine (Holmes, 2008. In other words, both 
large-scale social organization and everyday social practices shape how people behave. Gender is not just a fixed or static identity but is performed through everyday interactions and choices (Berkowitz, Manohar, \& Tinkler, 2010). Within this process, a binary division is created where masculine and feminine are opposites. The argument is that in contemporary Western society the two categories are not only considered as different and in opposition, but are also placed in a hierarchy where masculinity is often considered superior to femininity (Beasley, 2005). In a patriarchal society masculinity bias exerts power and privilege, whereas feminine bias is considered inferior.

In order to evaluate educational career choices as it relates to gender, it is necessary to examine the concept of gender stereotypes. This concept refers to commonly accepted beliefs about the activities and abilities of boys and girls, and men and women (Berndt \& Heller, 1986). Because of gender stereotypes, there is a division of labor where certain careers are typically classified as "men's jobs" and "women's jobs" (Padavic \& Reskin, 2002; Williams, 1993). For example, women are commonly stereotyped as being more caring in nature, and therefore, women are often steered into service-oriented careers where they care for others such as nursing, social work, and education (Anker, 1998; Deemer, Thoman, Chase, \& Smith, 2014). Gender stereotypes are not static nor are they identical on a global scale. They change over time, but often slowly due to hegemony, discrimination, and a clinging to popularly held beliefs by both men and women (Powell, Dainty, \& Bagihole, 2012; Reuben, Sapienza, \& Zingales, 2014). Because of social constraints such as social-cultural norms, stereotypes, and discrimination, certain occupations are heavily segregated across gender lines and thus become female-majority professions (Adams, 2010; Anker, Melkas, \& Korten, 2003).

Men choose female-majority professions with differing types of entry dynamics. Simpson (2005) categorized men entering into female-majority professions as "seekers" (men who made an active choice to enter the profession), "finders" (men who found their profession in the process of making general career decisions), and "settlers" (men who had tried other, often more traditionally male jobs, but with limited satisfaction before settling in their current profession). In Simpson's (2005) study, some variation existed amongst different categories in terms of career orientation. For example, those who were previously in other careers (settlers) voiced an intrinsic motivation for pursuing their new profession and wanted to remain close to professional practice. Many of the men in the study demonstrated a degree of role strain, or discomfort with gender role behavior based on tension between one's gender and societal gender stereotypes. This manifested itself in feelings of embarrassment that were mostly externally located and based on fears of how others might perceive them. Compensatory strategies to reduce embarrassment or shame included specialization in areas considered more masculine, and emphasizing more masculine aspects of the occupation such as opportunities for advancement to management, particularly when discussing their job with others. Ultimately, the importance of fit between the self and job outweighed the effects of role strain in making career choices. Selffulfillment and fit were found to be crucial components of job satisfaction.

Research has documented that men enter female-majority professions because of the combination between wanting to help others, job satisfaction, and job security (Boyd \& Hewlett, 2001; Byrne, 2008; Patterson \& Woodward, 1995). In Byrne's (2008) study investigating the influence of altruism in the career choices of male students in female-majority professions, both men and women indicated that the desire to help others played a significant part in career choice. However, female students indicated the desire for one-on-one relationships with patients whereas 
male students indicated more of a desire to contribute to society in general. The issue of altruism and helping others is strongly related to the important factor of perceived job satisfaction. Yet, it seems that how job satisfaction is perceived is sometimes stratified across gender lines. Patterson and Woodward (1995) examined key reasons for speech and language therapy as a career choice and also implicated the variable of job satisfaction. In their study, male students perceived job satisfaction as a function of salary and career advancement while female students related job satisfaction to the opportunity to work with and help people.

Several studies have focused on the choices, experiences, and challenges of male speechlanguage pathologists and students. In one study in Scotland, male SLPs described job security, professional autonomy, and an interest in a specific area of the profession as reasons for entering the profession (Boyd \& Hewlett, 2001). An important factor mentioned was previous exposure to actual speech-language pathologists whether that was through a professional connection or a personal one. The importance of exposure to an SLP was also echoed in Litosseliti and Leadbeater's (2013) study in the UK on the perspective of speech-language pathology as a gendered profession. In this research, the most important influences in career choice for both men and women were actual contact with an SLP and general exposure to the profession. Bending (2012) examined the experiences of male speech-language therapy students in the United Kingdom. She argued that male students noticed and felt a sense of isolation (physical, social, and psychological) as the only or one of the few males in their programs. They dealt with and confronted this isolation in different ways. Some of the men chose to ignore the isolation and focus on their studies. Others enacted strategies such as relying on peer support from another male in the program if available, engaging in outside activities with other males, separating their social lives from their professional lives, and challenging others' reactions to their difference. Although most of the students generally perceived their gender difference as positive, some of them also described some conflict between their gender and professional identities. Within the study many assumptions about male speech-language pathologists were discussed and questioned. In Bending's (2012) study as well in Litosseliti and Leadbeater's study (2012) there is a clear distinction between how certain professions including speech-language pathology are definitively female dominated versus being female oriented. Female-oriented reflects an implication that the nature and activities of the work itself is gendered according to stereotypical discourses around gender itself. To varying degrees, speech-language pathology was considered to be both female-dominated and female-oriented. A crucial component in these gendered discourses surrounds the concept of care as a feminine quality.

Societal norms have continually reinforced the notion that female-oriented careers, those typically constructed as "women's work" are based upon the dominant qualification of giving or providing care. Examples include teaching, nursing, and social work. Teaching itself, especially teaching in the early school years, is viewed as an act of care (King, 1998). Some have argued that nurturing and caring are strengths of women's culture, though they are not nor should they be exclusive to women (Noddings, 1992). Caring is an integral value necessary for teaching, as care is how teachers and students become meaningfully connected in the learning process (Noblit, Rogers, \& McCadden, 1995). Still, others have argued that the delineation of care as a fundamentally feminine quality is a method of subjugating women by positioning women's work as unskilled and less valuable in the labor market (Reskin, 1988). In this way, the devaluing of professions that emphasize care are both actions of and ramifications of sexism (Goldstein, 
2014). Men-- and women-- who enter into female majority professions must overcome this barrier.

This is particularly relevant for men who choose nursing, one of the most overtly gender segregated professions. Modern nursing has been constructed as a primarily female profession due in large part to historical events in which men and women have been occupationally segregated, and the very language and images associated with the nursing profession (Villeneuve, 1994). In fact, nurses who are men are frequently referred to as "male nurses" or "murses" to distinguish the assumption that all nurses are women (Rajacich, Kane, Williston, \& Cameron, 2013). Still, the number of men in nursing has more than tripled from $2.7 \%$ in 1970 to 9.6\% in 2011 (US Census Bureau, 2013). More men have gradually decided that nursing is a viable career option despite the gender stereotypes. Some research has shown that men are generally satisfied with their career choice, and would recommend nursing to other men (Twomey \& Meadus, 2008). Nursing research has mostly focused on barriers to male recruitment into the profession. However, there is also a limited amount of research on the experiences of male nursing students.

Researchers have argued that there are a number of gender-based barriers that men experience as they progress through nursing school. Several researchers used survey tools to assess the perceptions of male nursing students (Crigger, Luckman, \& Galusha, 2007; Keogh \& O’Lynn, 2007; Kermode, 2006; O’Lynn, 2004). Men in these studies reported a lack of mentorship in their programs, but also feelings of sexism and discrimination. Similarly, men reported some degree of marginality and discrimination on their clinical placements while in nursing school (Sedgwick \& Kellett, 2015). Several researchers have used a phenomenological approach to studying the experiences of males in nursing (Ellis, Meeker, \& Hyde, 2006; Ierardi, Fitzgerald, \& Holland, 2010; Meadus \& Twomey, 2011; Wilson, 2005). These studies have yielded a large variety of themes with some of the most prominent being the dynamics of their career choices to become a nurse, the role of caring within nursing, gender-based differences as students and as student nurses, and male nursing students' greater visibility in nursing school. Nursing research, much like the research in early childhood education, illustrates the need to actively study the experiences of men in female-majority professions in order to promote an appropriate learning environment for all students and future professionals.

\section{Purpose}

Based on previous research that investigates gender disparities, the experiences of men in female-majority professions, and due to the lack of research on gender disparities in speechlanguage pathology, it is important to gain some initial insight into the ways in which males decide on speech-language pathology as a career, and their experiences entering the profession. There is a need to include more male voices in the conversation about educational and occupational sex segregation. This is necessary in order to understand the decision-making processes of male students as well as their experiences in their training programs. Therefore, the research questions that guided this study were as follows: 1) What factors influence male graduate students' decision to pursue speech-language pathology? 2) How do male students enrolled in a speech-language pathology graduate program describe their experiences? 3) In what ways has gender affected the experiences of male students in a speech-language pathology graduate program?

\section{Methods}


This study employed a qualitative design with the goal of understanding how the participants in the study made sense of their situations, experiences, and actions (Maxwell, 2005). This research is based on the theoretical framework of constructivism (sometimes referred to as interpretivism), which assumes that multiple realities exist, and places importance on people's subjective experiences (Creswell, 2007). The researcher explores the ways in which participants experience and make sense of their world. In this theoretical framework, meaning is constructed between the researcher and participant. Several approaches exist within qualitative research, such as ethnography, phenomenology, case-study, and conversation analysis (Keegan, 2012). For this study, a multiple case-study design was conducted. The case-study approach involves defining a case (e.g., person, institution, or event), and analyzing the case in detail in order to contribute to an overall understanding of an issue (Creswell, 2007). The multiple case-study approach involves exploring more than one case, and comparing and contrasting findings across cases. In this study, the case was defined as male graduate students of speech-language pathology. The researchers were interested in exploring the subjective experiences and meanings the participants attached to their experience of choosing a career in speech-language pathology, their experiences in a graduate speech-language pathology program, and entering the profession of speechlanguage pathology.

\section{Participants, Setting, and Recruitment}

The four male participants were recruited by one of the authors, who is a faculty member in communication sciences and disorders. The specific author who collected the data, and information about the graduate program and institution, is not identified in this article in order to increase anonymity of the participants. The author had been an instructor for the students in a previous course, but was not teaching them at the time of their recruitment. Although there was a potential conflict of interest in recruiting students who were currently enrolled in one of the author's graduate programs, the university Institutional Review board had previously approved this research based on the author's written and verbal acknowledgement that students' participation or non-participation would not affect their status in the graduate program, nor would there be any negative consequences associated with their participation or nonparticipation in the study. The participants were sent a recruitment email and met with one of the authors to discuss the study and their consent. The participants were then interviewed separately, for 45-60 minutes in the author's office. The interviews were semi-structured in that the interviewer developed some guiding questions that were covered throughout the conversation. However, it many instances, the interviewer strayed away from the guide as needed in order to elicit the relevant experiences of the participant. The guiding questions focused on participants' recruitment into the field, influential factors or deterrents in their decision, the influence of gender on their classroom, clinical, and social experiences, and their perception of how gender influences the field as a whole including recruitment.

\section{Data Analysis}

Each interview was audio-recorded and transcribed verbatim. The transcripts were edited for anonymity, and pseudonyms were assigned to each participant. The interview transcripts were coded separately by both authors according to procedures of axial coding (Charmaz, 2014; Creswell, 2007). This process involves first reading through the transcripts to get an overall sense of the data. Next, the transcripts were read again, line by line, with the intention of assigning codes to units of data. A code is a summary word or phrase assigned to units of text (Charmaz, 2014). Coding serves as way to reduce the quantity of data to a manageable form for 
data analysis. Once codes were generated for each transcript, the authors grouped the codes according to common categories (e.g., "recruitment," "client interactions," "study group participation," etc.). Based on the categories of codes that were generated, themes emerged from the data; these represent common threads, or take-away messages, from each participant's story based on the research questions. The themes were generated based on common categories that kept emerging from the narratives.

\section{Subjectivity}

In qualitative, interpretive research, the very nature of the data and the data analysis is grounded in subjectivity (Morrow, 2005). This is the acknowledgement and recognition that the subjectivity of the researcher is intimately connected to the research. Both authors of this article are Black, male, full-time faculty members who once experienced life as racial and gender minorities in a graduate program in CSD. Thusly, both authors practiced reflexivity throughout the project including the processes of data collection, data analysis, and writing. Reflexivity is the process of the researchers engaging in self-aware meta-analysis (Findlay, 2002). For the first step in the process of reflexivity, each author reflected upon his former experiences as a graduate student, and current experiences as a faculty member and clinician. The authors wrote down some of these experiences and discussed them with each other. As students in graduate school, the authors' experiences included being self-aware of the ways in which gender (and in our case race) affected their conversations with classmates and study group dynamics. For example, the first author felt a sense of isolation as the only African American, and one of two male students in his cohort. He sometimes felt as though he had to push to be invited into study groups. Because of his perceived isolation, he only developed meaningful relationships with a few others in his cohort. He also felt an internal sense of pressure to perform well as a student given his status as the only African American male, and the first to ever graduate from his master's program. Based on the second author's experiences, classmates would often study or work on projects late at night in someone's home. However, the second author was always mindful of how his presence at a female's home late at night might appear, and, with few exceptions, participated in late-night study groups in the library. For the second step of reflexivity, the authors set aside their assumptions (a process known as bracketing) in order to mitigate the levels of bias in analysis and presentation of the data (Fischer, 2009). This included separating our own experiences from those of the participants in the study.

\section{Credibility}

This process ensures that the data accurately reflect the views and experiences of the participants. In qualitative research, credibility is typically achieved in four ways (Corcoran \& Stewart, 1998; Patton, 1990; Plexico, Manning, \& Levitt, 2009). First, as mentioned earlier, each interview was audio-recorded and transcribed verbatim. Second, also mentioned earlier, the authors engaged in bracketing to ensure that the results were not reflective of the author's biases. Third, the interviews were member-checked with participants in order to ensure accuracy of themes. This process involved the interviewer meeting with the participants a second time, and allowing them to clarify or make changes to the results if necessary. And fourth, both authors engaged in investigator triangulation, a process of discussing findings with each other. Unlike inter-rater reliability in quantitative research (which yields a number or score), the process of triangulation is a reflective discussion between researchers about the consistency and differences of themes that were generated, and deciding on a final theme structure. 


\section{Findings}

Findings are presented and discussed according to each case. The researchers describe and discuss each case through the lens of the three research questions: 1) What factors influence male graduate students' decision to pursue speech-language pathology? 2) How do students enrolled in a speech-language pathology graduate program describe their experiences? 3) In what ways has gender affected the experiences of male students in a speech-language pathology graduate program? The authors describe each case individually, but also summarize the themes of each case in Table 1.

Table 1

Major Themes of Participants' Experiences in a Speech-Language Pathology Graduate Program.

\begin{tabular}{|c|c|c|c|c|c|c|}
\hline $\begin{array}{c}\text { Participant } \\
\text { Name }\end{array}$ & Age & Race & $\begin{array}{l}\text { Year in } \\
\text { Program }\end{array}$ & $\begin{array}{l}\text { Exposure } \\
\text { to } \\
\text { Profession }\end{array}$ & $\begin{array}{l}\text { Recruitment } \\
\text { Motivation } \\
\text { Themes }\end{array}$ & $\begin{array}{c}\text { Gendered } \\
\text { Educational } \\
\text { Experiences Themes }\end{array}$ \\
\hline Ethan & 23 & White & 2nd & $\begin{array}{l}\text { Female } \\
\text { friend } \\
\text { referred } \\
\text { him }\end{array}$ & $\begin{array}{l}\text { - Versatility of } \\
\text { the } \\
\text { profession } \\
\text { - Challenges } \\
\text { of the } \\
\text { profession }\end{array}$ & $\begin{array}{l}\text { - Gender impact on } \\
\text { social group } \\
\text { dynamics } \\
\text { - Gender impact on } \\
\text { study group } \\
\text { dynamics } \\
\text { - Gender impact on } \\
\text { client and } \\
\text { clinician } \\
\text { interactions } \\
\text { - Gender as } \\
\text { motivation to meet } \\
\text { challenges }\end{array}$ \\
\hline Clayton & 26 & White & 2nd & $\begin{array}{l}\text { Female } \\
\text { friend } \\
\text { referred } \\
\text { him }\end{array}$ & $\begin{array}{l}\text { - Profession in } \\
\text { alignment } \\
\text { with } \\
\text { personal } \\
\text { strengths } \\
\text { - Opportunity } \\
\text { to help } \\
\text { people }\end{array}$ & $\begin{array}{l}\text { - Gender impact on } \\
\text { client and } \\
\text { clinician } \\
\text { interactions }\end{array}$ \\
\hline Karl & 52 & $\begin{array}{l}\text { Afric } \\
\text { an } \\
\text { Amer } \\
\text { ican }\end{array}$ & 2nd & $\begin{array}{l}\text { Observed } \\
\text { SLP } \\
\text { working } \\
\text { with a } \\
\text { friend }\end{array}$ & $\begin{array}{l}\text { - Profession as } \\
\text { continuation } \\
\text { of career in } \\
\text { service }\end{array}$ & $\begin{array}{l}\text { - Gender impact on } \\
\text { social group } \\
\text { dynamics } \\
\text { - Need for male and } \\
\text { minority providers } \\
\text { in the field. }\end{array}$ \\
\hline
\end{tabular}




\begin{tabular}{|c|c|c|c|c|c|}
\hline Logan & 24 & White $1 \mathrm{st}$ & $\begin{array}{l}\text { Career } \\
\text { referral } \\
\text { exam }\end{array}$ & $\begin{array}{l}\text { - Versatility of } \\
\text { the } \\
\text { profession } \\
\text { - Challenges } \\
\text { of the } \\
\text { profession }\end{array}$ & $\begin{array}{l}\text { - Gender as } \\
\text { motivation to meet } \\
\text { challenges } \\
\text { - Gender impact on } \\
\text { social group } \\
\text { dynamics. }\end{array}$ \\
\hline
\end{tabular}

Table 1 shows the findings of each participant's story with respect to the research questions. However, when looking across all four participants, the major theme that emerged was the enactment of critical strategies in order to adjust in a female-majority environment. The findings below will be discussed by presenting an introduction to each participant, representative participant quotes, and the author's interpretation of the findings.

\section{Ethan}

Ethan changed his major from early childhood education to speech-language pathology in his second year of college. Coming from a family of teachers, Ethan was drawn to the versatility of speech-language pathology, the implication of a higher salary than that of a classroom teacher, and the content and challenges presented in studying the field. Although he was not fully aware of the gender gap prior to pursuing speech-language pathology, he did not view gender difference as a deterrent to his educational experiences. However, his gender did pose a challenge at times and it did affect some of his social experiences in graduate school as well as how he believed his fellow students, faculty members, and clients perceived him.

The following quote summarizes Ethan's perspective on the ways in which gender affected his study group and social group dynamics:

It definitely changed the dynamic of how I will be able to study with certain groups like you know female students. .. . I knew as far as like all the girls in the program have like stay over like study sessions and sometimes I may not get invited to those just because they think the other guys in the program with me you know maybe we collaborate and we study together, that's not really the case. So I was kind of worried about how I was going to have to interact with my peers because I knew it was going to be a little different than just like half and half boy and girl, I knew it was a bunch of girls. Everybody has cliques. But I knew that we were going to have to figure something out on how I study with them, how I interact with my, because you goof off with males, you can play around and say certain things but in front of females, you know my mom taught me to be polite and all that kind of stuff. But as we have grown as cohort, I've learned I can play around with some of my other classmates. I've learned who to treat you know with this and some who will take jokes and goof off around.

Ethan discussed how his gender affected peer group dynamics, as he was one of the three male students in his cohort, and his strategies of adjustment. At the beginning of his graduate school experience, he was a bit worried about how to approach his social interactions with his female colleagues, as he knew that a large cohort naturally led to the establishment of "cliques" within the group. He felt that his natural outgoing personality was to "goof off" or joke around with his classmates. He also believed that this was a natural tendency for men in general. However, he was careful not to joke around with his female classmates before he learned their specific 
personality and that they would be receptive to it. Although it took some time, he got to know many of his female peers and learned how to interact with them.

Ethan's strategy of getting to know as many of his peers as possible was a helpful approach that also presented as a problem for him at times. He noted that most of the students in his cohort generally sat in the same place and with the same people in their classes. Ethan made it a point to sit in different places in his classes. He referred to this as "resourceful" because he wanted to get to know everyone, and different groups of students offered different things. As cliques developed, certain female students did not get along with others, and he was not always aware of these group dynamics. He said that this caused some tension toward him as well as some of his classmates" feeling that he was "using them." Because his presence was always highly visual as one of the few men, this was something difficult to deal with. He described the perception of some of his classmates:

They say, "See he's going over there to talk with them, and he sat with us yesterday. And he's probably getting help from here and getting help from here and there." They don't like them, so maybe like we're going to have to cut him off because he's hanging with them. Ethan felt that this perception of his strategy was unfair and a negative consequence of his gender. He perceived it as networking and believed that he was making the best use of his resources. He believed that he had certain strengths as a student but that it was advantageous to draw upon the strengths of his classmates as well.

Some of these strengths and weaknesses Ethan perceived as gender-based. He felt that his female colleagues were more competent in taking notes quickly and efficiently than the males in his cohort. Ethan considered himself a slow note-taker. He had a group chat with his other two male colleagues and they would sometimes use it to clarify points. Often he found that when he or one of the other two had missed something, they would go to one of their female colleagues to assist them. He also said that his female peers were far more creative and crafty when it came to providing therapy materials. He acknowledged that when he worked with child clients it would be beneficial to have more creative materials. However, he drew upon the concept that the difference in therapy styles was driven by gender. When describing the differing clinical styles of the males in his cohort he said, "We're there to get stuff done instead of worrying about how cute it is." The men he felt had a contrasting therapy style that was as effective but different. Although Ethan's intent was to illustrate some differences he interpreted between the male and female students, his observations could be perceived as essentialized notions of masculine and feminine characteristics. In arguing that his female colleagues were craftier and better at administrative tasks, while he and his male colleague were more goal-driven, he inadvertently placed higher value on the skills of he and his male colleagues. This is symptomatic of a patriarchal system in which the skills of women are devalued due to gender-based stereotypes within the larger society (Goldstein, 2014).

Despite Ethan's proactive strategy to cultivate relationships with his peers in order to succeed in graduate school, he still sometimes struggled to navigate the dynamics of peer study groups. He mentioned on several occasions that he was sometimes not invited to study groups, and that perhaps some women in the program assumed that he would be studying with the guys in the program. However, the men rarely did study together. He also described one specific study group situation that he felt was a bit discriminatory. 
And I like I've asked them like "hey you guys look like" (and I live close by) so I'm like "hey guys what are y'all up to?" There's a ton of cars over there, I can see it. They're like "oh we're just about to go to the gym together" or something but actually they are working on a study guide and talking about discussion posts and things like that. I completely miss it definitely because I'm a guy. If I came over, and I live right next door, I'm a part of the cohort, just like everybody else. I'm trying to learn the same stuff that they are all over there congregating and learning. They like make up something or tell me like "we're just going to the gym" or "we're all going out to eat together, we're not doing school work." So, that's been a little discriminatory.

Ethan later found out later from a female colleague that they were in fact working on a study guide and going over content for the exam. He said that they did not want to invite him because several of them were really casually and comfortably dressed because they didn't want to "put on more clothes" as they felt would be appropriate given that he was a man. Although he empathized with this, he didn't find it to be fair given the importance of the exam and how he could have benefitted from participation in the group.

\section{Clayton}

When Clayton was an undergraduate student majoring in criminal justice, a female friend had majored in speech-language pathology and he began to have some interest in the major. He did not pursue it at the time because he was already on track to graduate. However, he pursued speech-language pathology several years after completing his undergraduate degree in criminal justice. Clayton mostly expressed the benefits of being a male in speech-language pathology and only a few instances where he had a negative experience or a concern. Motivated by his desire to help people, Clayton perceived speech-language pathology to be an ideal career to assist people in improving their quality of life. He had decided that law enforcement was not a way to do this, and wanted to pursue a more benevolent field. He wanted to change lives but he also wanted to do something that complemented his strengths. He felt that he had found the perfect fit in speech-language pathology. It appealed to his personable nature, his strengths in communicating with others, and his need to help others.

Gender did not play a role in his decision to pursue the field, and rarely played a direct role in his interactions with his classmates, as indicated by his comment- "I mean it really hasn't been a difficulty at all. ... It's been really good. I've really been able to connect and really get along with basically every girl in the program." Clayton had had the opportunity to build relationships with many of his female colleagues through his courses and clinical experiences. He mentioned that once some of his colleagues mentioned the possibility of him receiving preferential treatment from professors. Clayton said that he did not think this was the case, but that he never gave it any thought after the conversation. He did mention that there were one or two instances where he wasn't selected by his peers for a group assignment, and he struggled to find another group:

There was time, two times when I didn't get picked to be in a group and I think it's because I was the guy. When I was like the only person that didn't get picked both times. I found someone else to be in group with and it worked out great but I think it was because maybe the girl didn't want to rub another girl the wrong way by not choosing her and so I got left out because I always like did my part with the group projects so I mean it was-it's a possibility that's what it was. 
Clayton felt that his gender played a role in this because he was the only person who was not selected, and he had always fulfilled his responsibilities in other group projects. Group dynamics and interpersonal relationships came into play because he reasoned that one of his female classmates did not choose him for fear of offending another female classmate. Still, Clayton reported that these instances did not truly bother him in a meaningful way as his gender was generally well received by his clients and their families.

In Clayton's on-campus clinical experiences, several of his clients had mentioned his gender in some positive way. Clayton believed that he had received one client because the client's parent had wanted a male role model for the young boy and believed that he would work better with a man:

There was one client's parent that wanted me in the room because I could handle the person like if physically things got out of hand that they wanted me to be in there so that ... was one time where it was actually, I guess, preferred by a parent of a patient. This frequently cited concept has been problematized in the literature (Martino, 2008). One of his other clients was an adolescent boy with autism who also had some behavioral issues. The client had several instances in the past where he had hit a teacher or therapist. This parent noted that they were glad that Clayton was one of the clinicians, as they liked having his male presence in the room if the boy began to demonstrate behaviors where he would hurt himself or others. His presence based on stereotypical gendered descriptions of men as being stronger was valued by the families of his clients in this specific situation. Clayton felt that his gender had a limited negative impact except in a few instances where his gender made his work more difficult.

Clayton expressed that as a man working with children he had to more careful than his female classmates. He felt that men working with children were more likely to be accused of inappropriate sexual behavior simply because of their gender. For example, he described how in a whole classroom language session he was once reading a story to some children. The children wanted to climb on his lap as he was reading, but he verbally and physically would not let them:

There was one situation. I don't know if this really applies to what you're asking but I was telling a story and kids wanted to get up on my lap but being a guy, I was like really not comfortable with that because you know, I know people you know some people might think like I'm doing something because I'm a guy but if I feel like there is a mentality that they, the parents might not want their kids in a room with a male.

He felt that some parents might not want their children alone in a room with a male therapist, but that this did not apply to a female therapist.

He also recalled how in one of his clinical experiences he participated in a language-based summer camp with a large group of students. At one point there were a group of boys who were playing around in the bathroom. He decided to go in to supervise them to ensure they were not making a mess or causing any other trouble in the bathroom. As he proceeded to do this, his clinical supervisor warned him to "be careful." Even though he was grateful that his supervisor was only trying to protect him, he felt that it was indicative of a time where his gender affected his ability to carry out his responsibilities with his clients. Although all people who work with children must be prudent in their interactions, he wondered if this same advice would have been given to one of his female classmates. These examples serve to show the ways in which Clayton had to enact strategies in order to adjust as a male student in a female-majority program. As a 
result of these experiences, Clayton has always attempted to be very careful within his interactions with children. When asked to describe his displeasure with this dynamic, he said, "I don't like that personally, because I don't have any background, anything, like that, where I've done something wrong. So I think that's the biggest thing I've had to encounter or might encounter in the field of speech." Despite his apprehension about potential unwarranted accusations, Clayton was very happy with his choice to pursue speech-language pathology. He thought it was a good field for men to enter into, but he thought that many men probably thought that the field was mostly about working with little kids. He didn't feel that speech had the same stigma that a field such as nursing had. However, he felt that it was generally not marketed well to men and was under-marketed to students in general.

\section{Karl}

Karl was a retired veteran with over 20 years of military experience. He had served in a variety of positions in the military, including that of a chief in which he supervised others. Even though he had retired, he still felt a strong sense of obligation to check on his comrades, many of whom had dealt with issues of depression, post-traumatic stress disorder, and other combat related injuries. Karl described how one day he visited one of his men who had suffered from a traumatic brain injury, and they were seeing a speech-language pathologist. He had never heard of this profession, but he was intrigued by what he saw. In time, he noticed improvement in the condition of his friend. Karl then decided that pursuing a career as a speech-language pathologist was the best way to help his comrades and help others.

In doing observations at the veteran's hospital, and talking with other speech-language pathologists, Karl came to the realization that speech-language pathology was a female-majority field. He felt some initial apprehension about this because he wasn't sure how he would fit in. He was older, a man, and still heavily ingrained in military culture. He was still adjusting to civilian life, and he knew going back to school to get both an undergraduate and graduate degree would be a tremendous challenge. Karl talked about how in his time in the military he did not have a lot of experience working with women. Therefore, Karl based many of his expectations on his experiences growing up and being raised around mostly women. For example, Karl discussed how one issue that he did not like was "mood swings" and negative attitudes, particularly in a work setting. Although these are essentialized and perhaps denigrating concepts of how women interact and communicate, they were ideas he associated with women based on his upbringing and past experiences, and could have potentially affected his decision to enter the profession. Still, he felt that going into speech-language pathology was his second calling in order to help his comrades and "heal that part of their lives."

Karl described his female colleagues as being mostly very supportive, and that gender rarely caused an issue for him. Despite his initial hesitations, Karl found his concerns to be mostly unfounded, at least in how his female colleagues interacted with him directly.

I haven't heard anything negative at all. Um, I would say $99 \%$ of the girls have been very supportive and we really hardly talk about [the] gender aspect of it. I can't recall a conversation where they may ask why are you a male and you're doing this? Most of the people that know me know why I want to do this. Because we used to have to stand up and introduce ourselves in some of the classes and say why we wanted to be. I told them 
why I wanted to be that and I started that almost I guess about 3 years ago. So, they have been very supportive of it and they support veterans.

However, Karl has employed various strategies in order to fit in and get along. For example, he made a conscious effort to talk with all of the various members of his cohort. He avoided trying to be put into a group or clique because he did not want others to label him. He also made himself available to help his classmates with certain tasks such as offering them advice about their cars, even working on their cars, and tasks in which he considered himself handy. He also attempted to always avoid negativity. He said that very often certain classmates would talk negatively about other classmates. He purposefully would avoid these conversations or he described a process in which he would "stop, look, and listen" but not get involved in it. $\mathrm{He}$ called this "playing the politics" to avoid confrontation and negativity.

Although he said that most of his female colleagues were generally supportive of him, he sometimes had difficulty when it came to class assignments. He did not necessarily feel as though they intentionally discriminated against him because he was a male. He did feel as though cliques developed, and sometimes he wasn't picked for a variety of factors. He was significantly older than almost all of his classmates, male, and African American. He said that he sometimes had to force his way into groups for assignments if the professor didn't select them. He was not in study groups but mostly studied by himself. Yet, he frequently stated that everyone was generally nice to him, and would invite him to social events when they occurred.

Karl did find that his gender helped him to relate to his clients and their families. All three of his clients in his first year had been male and had included a child, an adolescent and an adult in his forties. Karl said that the parents and caregivers had told him that his clients were really comfortable with him, and that they had enjoyed having him as a clinician. Karl reasoned that at least a part of this was because he was man. He also worked hard at developing relationships with his clients as a part of developing his clinical skill set. He also talked about how he had formed a bond with a patient at his group clinical rotations in a skilled nursing facility. This happened to be an older gentleman who was also a veteran. The staff members at the facility talked about how typically, the man was very quiet. Yet, Karl had developed a rapport with the patient in talking at length about the military, family, and other things. Karl felt that he was able to develop this relationship because the patient related to him as a man and as a veteran.

Karl was the most adamant out of the participants that the demographics of speech-language pathologists should more closely resemble that of society. He felt that there should be more men, and also more minority men. He talked about the role of culture in providing therapy, and how it was important that therapists understood the "unseen and unwritten rules" of a given culture. He said that more school-based male and minority SLPs could help with some of the issues plaguing minority youth. Karl stated that there weren't as many men in the field because of traditional gender roles and gender stereotypes. Salary, he said, was a major barrier. Many men wanted to be a provider for their families, and the SLP salary was not as much when you factor in how much schooling was necessary and how student loans could accrue. Karl said that men gravitated toward jobs that were viewed as "men's jobs" such as an engineer or a trade such as an electrician. Karl felt that a part of this was because speech-language pathology was not well marketed and underexposed. He also said that men likely viewed the field as playing with small children, but that they didn't understand the science behind it. 
Finally, Karl reasoned that a lot of men would not be interested in fields such as speech-language pathology because they required compassion and care as a prerequisite. He explained:

A lot of this has to be from your heart. You know, you use evidence-based practice, but you got to usher that with your heart. The attachment, the unseen part with a patient has to be the heart part. I don't think a lot of men like to show their heart. They aren't brought up to show compassion.

Karl felt very inspired and connected to the profession. He had had some challenges in graduate school, but overall, his experiences were mostly positive. He felt that gender was a very important topic as well as the recruitment of men and minorities into speech-language pathology.

\section{Logan}

Logan had taken a personality-based career test in high school, and speech-language pathology was one of the fields that was implicated as a fit him. After doing more research, he decided to pursue the field in college. Logan valued the job security of speech-language pathology as well as the versatility and the challenge:

So it was seeing the job security that really pulled me in and on top of that, how broad the field is. So say I went into one side of it and got bored with it? I could easily switch to something else? And the continuing education aspect of it. I love the idea of constantly building on your knowledge, especially due to the information being added into the field. I feel like it is constantly growing.

Logan had had some experiences working many hours in factories, and knew that he did not want something repetitive. He wanted to embrace fresh and new challenges in his career.

Logan knew that he had to rise to the challenge very early on when he began taking classes in his major as an undergraduate. Prior to that, he was not really aware that the majority of students and professionals in speech-language pathology were women. As he sat in class as the only male, he knew that he was going to be in the "spotlight" because he was in the minority and was so easily recognizable. He felt that if he was absent, or did not perform well, his instructors would notice fairly quickly. Therefore, he was motivated to do his best. He said that one or two of his instructors had even joked about this aspect of his high visibility. However, he felt encouraged and motivated by this. He did not necessarily feel negative pressure, but instead felt supported.

Logan discussed the social dynamics of assimilating into a cohort as the only male. He said that he felt that there was an unspoken competitive undercurrent in graduate school, and that this was probably true of every cohort. He felt as though his gender may have added to this tension in the beginning. Some of his classmates may have initially been not as accepting because they felt he may have had an unfair advantage within the competition. However, he said that once they learned that he was there to learn, get along with everyone, and contribute, he said that the tension dissolved fairly quickly:

It has come up a lot. With classmates, I kind of feel like they think I am going to get a spot over them so I feel like there is competition but again, at the same time, it is like an unfair competition. So with some classmates, it creates kind of that weird vibe but then they realize I am here to get along with everybody and build off of each other so I guess that kind of negates that weird tension at first. 
One of the biggest challenges for Logan was where he would sit during class and other events, and how to navigate social situations. One of his fears was that some of his female colleagues might accuse him of being flirtatious in certain situations. He said he had once dated someone as an undergraduate student and it turned into a negative experience. Therefore, he was very careful with how communicated with his colleagues and always tried to do so in a professional manner. When describing his approach, he said, "I wanted to be reserved because I wanted to be viewed as more of a professional, versus here's the guy trying to be in this field with all these girls and just slip under the radar." Logan practiced careful impression management in how he wanted to be viewed, and this was influenced by his gender as he was the only male in his cohort. He felt the need to rise to a high level of expectation given his high visibility. He was careful with how he interacted with his female colleagues as he didn't want to have a negative reputation. He described a situation where he was in a group with a female colleague, and he offered a counter point of view to the direction of the project that they were going in. He said that his point of view was disregarded by his classmate. Rather than argue with her, he decided to let his point go because he did not want to be perceived as this "male jerk." He decided that he wouldn't work with this student anymore because they weren't compatible as partners given that his opinion was not valued.

\section{Discussion}

This study was designed to provide some initial insights into the reasons why men choose the career of speech-language pathology, their experiences in speech-language pathology graduate programs, and ways that gender might affect those experiences. Little research has been conducted in the area of gender disparity in speech-language pathology. This study adds to the literature by illuminating the voices of male speech-language pathology graduate students in order to understand their choices, experiences and perspectives.

The participants in this study entered the profession for reasons such as versatility, opportunities to help others, job security, and prospects of a higher salary than some other service-oriented professions such as teaching. These findings reflect the findings in Byrne's (2008) study on the influence of altruism and Simpson's (2005) study describing "seekers," "finders," and "settlers," as general categories for reasons why men enter female-majority professions. The combination of higher salary and the wide range of work prospects could present as a significant recruiting advantage for the field of speech-language pathology. In this study, gender appeared to play an insignificant role in the selection of speech-language pathology as a career. Furthermore, the participants in this study did not demonstrate role strain, which is the disparity between the masculine gender role behavior and the female associated attributes of their job, as they did in Simpson's (2005) study. However, some participants did identify gender-based differences in therapy styles and learning styles that could be considered essentialized notions of masculinity and femininity. Also, some of them mentioned the stereotypical societal expectation as the man as the "provider" for the family and how that expectation could potentially sway them and men in general to work in the medical setting because of the higher pay. Higher salary and versatility are obviously attractive qualities of a career for both men and women. However, because of the previously discussed persistent gender stereotypes that men are financial providers, and care as "women's work," these two attributes seem to be particularly meaningful for recruiting men considering speech-language pathology. Interestingly, not only does gender disparity exist with the profession, it also exists within speech-language pathology workforce settings, as there are fewer male speech-language pathologists in school settings than university or health care settings 
(ASHA, 2013; ASHA, 2016b). As ASHA continues to work toward its strategic imperative to diversify the background of the workforce, an emphasis should be placed on versatility of the professions, the robust job market, and the competitive salaries within each area of practice. The participants felt that gender could pose as a barrier to recruiting more men into the professions, but not one that was particularly significant or insurmountable. Instead, they generally felt that a lack of exposure to the profession was a key reason for the gender disparity.

Findings of the case-studies presented in this research indicated that gender can influence the experiences that men have in graduate programs. Generally, these students perceived their gender to be a positive attribute as it helped them connect with their clients who were boys and also adult men. In particular, they believed that they could serve as role models for their child clients. This is a heavily referenced and cited rationale in the literature for recruiting male teachers (Dermott, 2012). This was continually reinforced by the words and the actions of the families of their child clients. The literature has analyzed how this frequently reinforces a heteronormative hegemonic masculinity (Cushman, 2008), yet the participants in this study did not perceive it this way. The male students in this study consistently highlighted the importance of caring as prerequisite for this type a work, an idea also echoed in the literature (Collier, 2005). They viewed their gender as a way to connect with, and build relationships with their male clients because sometimes males identified better with males. Despite the overall positive response they received from being male speech-language pathology students, their gender did present some specific challenges. This study revealed how these male students enacted intentional, critical strategies in order to adjust in their female-majority environment, which manifested in different ways for each participant.

The participants discussed the impact of their gender as primarily affecting study group dynamics, social group dynamics, and clinical interactions. The motivations, experiences, and challenges of these students were in many ways similar, to those of the authors. As seen in this study, male students sometimes have to navigate cautiously their interactions with female students, and their interactions with child clients. Bending (2012) revealed how male speechlanguage students in the United Kingdom dealt with and confronted social isolation in their graduate programs. The participants in Bending's study used intentional coping mechanisms to combat the psychological effects of being a minority within a cohort. However, the present study documents that male speech-language pathology students are very intentional in the ways that they deal with the social challenges of being a male student in a female majority profession. For them, the social dynamics affect their professional growth and their ability to navigate through the rigors of graduate school. They do so in order to support their burgeoning development as professionals in their field. Several of the participants described their intentionality in getting to know, or ingratiating themselves with their female colleagues in order to navigate their social interactions and overall success in graduate school. They also described how those efforts had backfired on them because of complicated social group dynamics. Other critical strategies that were used involved their cautious approaches to working with children, and conscientious impression management. The use of extreme caution out of fear of child abuse allegations as a male professional is a theme frequently explored in the early childhood literature (King, 1998). This is a perhaps unfair, but real consequence of being a male who has chosen a female-majority profession such as speech-language pathology. Also, much like the nursing students in Meadus \& Twomey's (2011) study, the males in this study described a feeling of increased expectations based on their high visibility because of their gender. These increased 
expectations were not made explicit by classmates, supervisors, or professors per se. Yet, this was something that the participants felt, and responded with their actions, efforts, and interactions. These students felt the need to go to careful lengths to always be in class, to do their best in class and always present as a willing and cooperative team member on collaborative projects. This unspoken pressure has the potential to add additional stress to the graduate school experience, though it did not appear to do so for these students. This study bears ramifications for the ways that we orient students and advise them. Social dynamics may pose challenges that need to be explored as we help students navigate through our programs. This is helpful for all students, and not just those who are underrepresented in the field. Doing so helps to promote a more collaborative and ideal learning environment.

\section{Conclusion}

This study is one of few studies in the United States that has examined the experiences of male students in speech-language pathology. Based on the findings, we offer the following recommendations for addressing the gender gap and the recruitment and retention of male students in graduate speech-language pathology programs:

- When promoting the SLP profession, the recruitment efforts of ASHA and its members should focus on the wide range of work opportunities, salary benefits, and robust job market, as well as the beneficial impacts that clients have experienced from SLPs.

- Faculty members, advisors, and clinicians should seek opportunities to promote the SLP profession during events such as high school and undergraduate open houses. In particular, male students and male SLPs can be influential in encouraging future male students to pursue the profession.

- Faculty members should approach teaching and advising from a student-centered perspective via an ethos of caring (Ginsberg, 2018). Caring about students includes being open to, and even initiating conversations that go beyond academic content. Faculty members should be willing to help students' problem-solve difficult social challenges in graduate school, and the potential isolation and pressure that comes with being an underrepresented student within a graduate program (Matthews at al, 2018).

- Supervisors should be mindful of the ways in which males might perceive and approach interactions with child clients. However, male students should not be singled out as though they are more predatory. Prudent advice for dealing with the liability associated in working with children should be provided to male and female students alike.

- Instructors and supervisors should be attentive to diverse student learning styles and clinical approaches while building on students' strengths.

- Researchers should conduct more large-scale survey studies, qualitative studies, and focus group studies of male experiences in order to increase our understanding in this area.

\section{Limitations and Future Directions}

Due to the nature of this case-study design, findings of this study cannot be generalized to a larger population of male graduate students. Instead, the findings provide some insights into experiences that male students of speech-language pathology might have in graduate programs. As mentioned above, future studies can explore gender disparities of speech-language pathology in a larger population through either qualitative or quantitative designs. In addition, future studies can also explore experiences of male clinicians who are currently practicing as speech- 
language pathologists. By exploring gender disparities, research can uncover new insights into closing the gender gap so that client populations can benefit from a diverse body of practitioners. 


\section{References}

Adams, T. L. (2010). Gender and feminization in health care professions. Sociology Compass, 4(7), 454-465.

American Speech-Language Hearing Association. (2007). ASHA summary membership and affiliation counts, year-end 2005. Retrieved from http://www.asha.org/uploadedFiles/research/memberdata/2005MemberCounts.pdf

American Speech-Language-Hearing Association. (2013). 2013 Membership survey. CCC-SLP survey summary report: Number and type of responses. Available from www.asha.org.

American Speech-Language Hearing Association. (2015). ASHA strategic pathway to excellence. Retrieved from http://www.asha.org/About/Strategic-Pathway/

American Speech-Language Hearing Association (2016a). ASHA summary membership and affiliation counts, year-end 2015. Retrieved from http://www.asha.org/uploadedFiles/2015-Member-Counts.pdf

American Speech-Language-Hearing Association. (2016b). 2015 Work life survey. CCC-SLP survey summary report: Number and type of responses. Available from www.asha.org

American Speech-Language Hearing Association (2018). Strategic objective highlights.

Retrieved from https://www.asha.org/uploadedFiles/Strategic-Objective-Highlights.pdf

Anker, R. (1998). Gender and jobs: Sex segregation of occupations in the world.

Geneva, Switzerland: International Labour Organization.

Anker, R., Melkas, H., \& Korten, A. (2003). Gender-based Occupational Segregation in the 1990s (WP-16). Geneva, Switzerland: International Labour Office.

Beasley, C. (2005). Gender and sexuality: Critical theories, critical thinkers. London, England: Sage Publications, Inc.

Bending, H. R. (2012). Becoming a speech and language therapist; A qualitative exploration of the experiences of male speech and language therapy students and early career professionals. Retrieved from https://ore.exeter.ac.uk/repository/handle/10871/8481

Berkowitz, D., Manohar, N. N., \& Tinkler, J. E. (2010). Walk like a man, talk like a woman: Teaching the social construction of gender. Teaching Sociology, 38(2), 132-143.

Berndt, T. J., \& Heller, K. A. (1986). Gender stereotypes and social inferences: A developmental study. Journal of Personality and Social Psychology, 50(5), 889. 
Boyd, S., \& Hewlett, N. (2001). The gender imbalance among speech and language therapists and students. International journal of language \& communication disorders, 36(sup1), 167-172.

Byrne, N. (2008). Differences in types and levels of altruism based on gender and program. Journal of Allied Health, 37, 22-29.

Carding, P. N., Roulstone, S., Northstone, K., \& ALSPAC Study Team. (2006). The prevalence of childhood dysphonia: a cross-sectional study. Journal of Voice, 20(4), 623-630.

Centers for Disease Control (2016). Rates of TBI Related Emergency Department Visits, Hospitalizations and Deaths by Sex-United States, 2001 - 2010. Retrieved from http://www.cdc.gov/traumaticbraininjury/data/rates_bysex.html

Charmaz, K. (2014). Grounded theory in global perspective: Reviews by international researchers. Qualitative Inquiry, 20(9), 1074-1084.

Christensen, D. L., Bilder, D. A., Zahorodny, W., Pettygrove, S., Durkin, M. S., Fitzgerald, R. T., Rice, C., Kurzius-Spencer, M., Baio, J. \& Yeargin-Allsopp, M. (2016). Prevalence and characteristics of autism spectrum disorder among 4-year-old children in the autism and developmental disabilities monitoring network. Journal of Developmental \& Behavioral Pediatrics, 37(1), 1-8. Retrieved from http://www.cdc.gov/mmwr/volumes/65/ss/ss6503a1.htm\#suggestedcitation

Collier, M. D. (2005). An ethic of caring: The fuel for high teacher efficacy. The Urban Review, 37(4), 351-359.

Connell, R. W., \& Messerschmidt, J. W. (2005). Hegemonic masculinity: Rethinking the concept. Gender \& society, 19(6), 829-859.

Corcoran, J. A., \& Stewart, M. (1998). Stories of stuttering: A qualitative analysis of interview narratives. Journal of Fluency Disorders, 23(4), 247-264.

Creswell, J. W. (2007). Qualitative inquiry and research design: Choosing among five approaches ( $2^{\text {nd }}$ ed.). Thousand Oaks, CA: Sage Publications, Inc.

Crigger, N. J., Luckman, R., \& Galusha, C. (2007). Do we discriminate?. Men in Nursing, 2(5), 26-31.

Cushman, P. (2008). So what exactly do you want? What principals mean when they say 'male role model'. Gender and Education, 20(2), 123-136.

Dee, T. (2004). The race connection. Education Next 4(2), 53-59.

Deemer, E. D., Thoman, D. B., Chase, J. P., \& Smith, J. L. (2014). Feeling the threat: Stereotype 
threat as a contextual barrier to women's science career choice intentions. Journal of Career Development, 41(2), 141-158.

Dermott, E. (2012). 'Troops to Teachers': Solving the problem of working-class masculinity in the classroom?. Critical Social Policy, 32(2), 223-241.

Egalite, A. J., Kisida, B., \& Winters, M. A. (2015). Representation in the classroom: The effect ofown-race teachers on student achievement. Economics of Education Review, 45, 4452.

Ellis, D.M., Meeker J.B., \& Hyde, L.B. (2006). Exploring men's perceived educational experiences in a baccalaureate program. Journal of Nursing Education, 45(12), 523.

Findlay, L. (2002). Negotiating the swamp: The opportunity and challenge of reflexivity in research practice. Qualitative Research, 2(2), 209-230.

Fischer, C. (2009). Bracketing in qualitative research: Conceptual and practical matters. Psychotherapy Research Methods, 19(4-5), 583-590.

Galman, S. C., \& Mallozzi, C. (2015). The Ballad of the Big Manly Guy: male and female teachers construct the gendered careworker in US early education contexts. In Men, Masculinities and Teaching in Early Childhood Education (pp. 64-74). New York, NY: Routledge.

Ginsberg, S. M. (2018, April). Stories of success: African American speech-language pathologists' academic resilience. Teaching and Learning in Communication Sciences \& Disorders 2, (3), 1-15. Available at https://ir.library.illinoisstate.edu/tlcsd/vol2/iss3/4/

Goldberg B. (1994). A few good men. ASHA 36(11).

Goldstein, D. (2014). The teacher wars: A history of America's most embattled profession. New York, NY: Anchor.

Griffiths, M. (2006). The Feminization of Teaching and the Practice of Teaching: Threat or Opportunity? Educational Theory, 56(4), 387-405.

Hegde, M. N. (2010). Language and grammar: A behavioral analysis. The Journal of Speech and Language Pathology - Applied Behavior Analysis, 5(2), 90-113.

Hegde, M. N., \& Peña-Brooks, A. (2008). Treatment Protocols for Articulation and Phonological Disorders : Sound Stimuli. San Diego, CA: Plural Publishing, Inc. 
Holmes, M. (2008). Gender and everyday life. London: Routledge.

Ierardi, J. A., Fitzgerald, D. A., \& Holland, D. T. (2010). Exploring male students' educational experiences in an associate degree nursing program. Journal of Nursing Education, 49(4), 215-218.

Keegan, L. C. (2012). Review of research methods in communication disorders. Contemporary Issues in Communication Science \& Disorders 39, 98-104.

Keogh, B., \& O'lynn, C. (2007). Male nurses' experiences of gender barriers: Irish and American perspectives. Nurse Educator, 32(6), 256-259.

Kermode, S. (2006). Is nurse education sexist? An exploratory study. Contemporary Nurse, 22(1), 66-74.

King, J. R. (1998). Uncommon caring: Learning from men who teach young children. New York: Teacher College Press.

Litosseliti, L., \& Leadbeater, C. (2013). Speech and language therapy/pathology: Perspectives on a gendered profession. International Journal of Language and Communication Disorders, 48, 90-101.

Mallozzi, C., \& Galman, S.C. (2015). The Ballad of the Big Manly Guy: male and female teachers construct the gendered careworker in US early education contexts. In S. Brownhill, J. Warin, \& I. Wernersson (Eds.). Men, Masculinities and Teaching in Early Childhood Education (pp. 64-74). London: Routledge.

Martino, W. J. (2008). Male teachers as role models: Addressing issues of masculinity, pedagogy and the re-masculinization of schooling. Curriculum Inquiry, 38(2), 189-223.

Matthews, J., Ginsburg, S., Gregory, K., Love, J., Skiados, M., \& Wiggins, E. (April 2018). The recruitment and retention of underrepresented groups in SLP and Audiology. Invited panel presented at the National Black Association of Speech-Language Hearing Association annual conference, Crystal City, VA.

Maxwell, J. A. (2005). Qualitative research design: An interactive approach. (2nd ed). Thousand Oaks, CA: Sage Publications, Inc.

Meadus, R. J., \& Twomey, J. C. (2011). Men student nurses: The nursing education experience. Nursing Forum, 46(4), 269-279. doi: 10.1111/j.1744-6198.2011.00239.x 
Morrow, S. L. (2005). Quality and trustworthiness in qualitative research in counseling psychology. Journal of counseling psychology, 52(2), 250.

Noblit, G. W., Rogers, D. L., \& McCadden, B. M. (1995). In the meantime: The possibilities of caring. Phi Delta Kappan, 76(9), 680.

Noddings, N. (1992). Social studies and feminism. Theory \& Research in Social Education, 20(3), 230-241.

O’Lynn, C. E. (2004). Gender-based barriers for male students in nursing education programs: Prevalence and perceived importance. Journal of Nursing Education, 43(5), 229-236.

Padavic, I., \& Reskin, B. F. (2002). Women and men at work. Thousand Oaks, CA: Pine Forge Press.

Patterson, A. M., \& Woodward, R. J. (1995). Choice of speech and language therapy as a career. International Journal of Language \& Communication Disorders, 30, 25-33.

Patton, M. Q. (1990). Qualitative evaluation and research methods. Thousand Oaks, CA: Sage Publications, Inc.

Peña-Brooks, A., \& Hegde, M. N. (2007). Assessment and treatment of articulation and phonological disorders in children: A dual-level text. Austin, Tx: Pro-ed.

Powell, A., Dainty, A., \& Bagihole, B. (2012). Gender stereotypes among women engineering and technology students in the UK: Lessons from career choice narratives. European Journal of Engineering Education, 37(6), 541-556.

Rajacich, D., Kane, D., Williston, C., \& Cameron, S. (2013). If they do call you a nurse, it is always a "male nurse": Experiences of men in the nursing profession. In Nursing Forum, 48(1),71-80.

Reskin, B. F. (1988). Bringing the men back in: Sex differentiation and the devaluation of women's work. Gender \& Society, 2(1), 58-81.

Reuben, E., Sapienza, P., \& Zingales, L. (2014). How stereotypes impair women's careers in science. Proceedings of the National Academy of Sciences, 111(12), 4403-4408.

Rowden-Racette, K. (2013). Where the boys aren't. The ASHA Leader 18(8), 46-51.

Sedgwick, M. G., \& Kellett, P. (2015). Exploring masculinity and marginalization of male undergraduate nursing students' experience of belonging during clinical experiences. Journal of Nursing Education, 54(3), 121-129. 
Simpson, R. (2005). Men in non-traditional occupations: Career entry, career orientation and experience of role strain. Gender, Work \& Organization, 12(4), 363-380.

United States Census Bureau (2013). Male nurses becoming more commonplace, census bureau reports. Retrieved from https://www.census.gov/newsroom/press- releases/2013/cb1332.html

Villeneuve, M. J. (1994). Recruiting and retaining men in nursing: A review of the literature. Journal of Professional Nursing, 10(4), 217-228.

Werven, G. (1994). Perspectives on the male speech-language pathologist. American Speech-Language Hearing Association Journal, 36(11), 42-45.

Williams, C. L. (Ed.). (1993). Doing" women's work": Men in nontraditional occupations (Vol. 3). Newbury, CA: Sage Publications, Inc.

Wilson, G. (2005). The experience of males entering nursing: A phenomenological analysis of professionally enhancing factors and barriers. Contemporary Nurse, 20(2), 221-233. 